\title{
Evidence of different habitat use by New Zealand freshwater eels Anguilla australis and $A$. dieffenbachii, as revealed by otolith microchemistry
}

\author{
Takaomi Arai ${ }^{1, *}$, Aya Kotake $^{2}$, P. Mark Lokman ${ }^{3}$, Michael J. Miller ${ }^{2}$, Katsumi Tsukamoto ${ }^{2}$ \\ ${ }^{1}$ International Coastal Research Center, Ocean Research Institute, The University of Tokyo, 2-106-1, Akahama, Otsuchi, \\ Iwate 028-1102, Japan \\ ${ }^{2}$ Ocean Research Institute, The University of Tokyo, Nakano, Tokyo 164-8639, Japan \\ ${ }^{3}$ Department of Zoology, University of Otago, PO Box 56, Dunedin 9001, New Zealand
}

\begin{abstract}
The apparent use of marine and freshwater habitats by Anguilla australis and A. dieffenbachii was examined by analyzing the strontium ( $\mathrm{Sr}$ ) and calcium (Ca) concentrations in otoliths of silver eels collected from Lake Ellesmere, which is a shallow brackish-water coastal lagoon in New Zealand. The age and growth of these eels was also examined using their otolith annuli. Size and ages of females were greater than those of males for both species. Growth rates were similar among sex and species, but the highest growth rates were observed in eels that experienced saline environments. Line analyses of Sr:Ca ratios along a life-history transect in each otolith showed peaks (ca. 15 to $21 \times 10^{-3}$ in A. australis, 14 to $20 \times 10^{-3}$ in A. dieffenbachii) between the core and elver mark, which corresponded to the period of their leptocephalus and early glass eel stage in the ocean. Outside the elver mark, the Sr:Ca ratios indicated that eels had remained in different habitats that included freshwater (average Sr:Ca ratios, 1.8 to $2.4 \times 10^{-3}$ ), areas with relatively high salinities (average Sr:Ca ratios, 3.0 to $7.4 \times 10^{-3}$ ), and in some cases individuals showed clear evidence of shifts in the salinity of their environments. These shifts either indicated movements between different locations, or changes in the salinity of the lake. There were more individuals of $A$. australis that used areas with intermediate or high salinities, at least for a short time (85\% of individuals), than $A$. dieffenbachii $(30 \%)$. These findings suggest that these 2 southern temperate species may have the same behavioral plasticity regarding whether or not to enter freshwater or remain in marine environments, as has been recently documented in several northern temperate anguillid species.
\end{abstract}

KEY WORDS: Anguilla dieffenbachii - Anguilla australis · Age $\cdot$ Growth · Otolith microchemistry • Habitat use $\cdot$ Lake Ellesmere $\cdot$ New Zealand

Resale or republication not permitted without written consent of the publisher -

\section{INTRODUCTION}

In contrast to most other temperate regions that are primarily inhabited by single species of freshwater eel of the genus Anguilla, New Zealand freshwater habitats are inhabited by 2 species of temperate eels, with a third that appears to occasionally recruit there. The 2 species that commonly occur throughout New Zealand are the longfinned eel $A$. dieffenbachii and the short- finned eel $A$. australis, and the third species that has been recently reported there is the more tropical species A. reinhardtii (see McDowall et al. 1998). The longfinned eel is unusual in that it is endemic to the relatively small landmass of New Zealand and reaches much larger sizes than other temperate eels, while the shortfinned eel occurs not only in New Zealand, but also in southeast Australia and Tasmania, New Caledonia, Norfolk Island, and Lord Howe Island (Ege 
1939). Both species are common throughout New Zealand; however, there does appear to be some degree of habitat segregation between the two (McDowall 1990, Jowett \& Richardson 1995, Glova et al. 1998).

The life cycle of the New Zealand freshwater eels is identical to all other anguillids in having 5 principal stages, which are the leptocephalus, glass eel, elver, yellow and silver eel stages (Bertin 1956). It is believed that, like the larvae (leptocephali) of other temperate eels such as Anguilla anguilla, A. rostrata and $A$. japonica, leptocephali of New Zealand freshwater eels drift with oceanic currents from their open ocean spawning grounds to their growth habitats on the various South-Pacific land masses (Sloane 1984, Jellyman 1987, Arai et al. 1999). The leptocephali of all these species presumably leave oceanic currents after metamorphosing into glass eels, and then typically migrate upstream as elvers to grow in freshwater habitats during the yellow stage. At ages that vary widely among individuals of both sexes, but especially for the larger older females in the yellow eel stage, the yellow eels metamorphose into silver eels, which migrate downstream to the ocean to begin the journey to their offshore spawning areas (Tesch 1977).

Recently, the migratory history of several species of anguillid eels has been studied using analytical microchemical techniques to determine the ratios of strontium to calcium (Sr:Ca) in the otoliths of fish (Campana 1999). The Sr:Ca ratio in the otoliths of fishes differs between the time they spend in freshwater and seawater (Secor \& Rooker 2000), and this has also been found to be true for anguillid eels (Tzeng 1996, Arai et al. 1997, 2003, Tzeng et al. 1997, 2000, Kawakami et al. 1998, Tsukamoto et al. 1998, Tsukamoto \& Arai 2001, Jessop et al. 2002). Thus, the $\mathrm{Sr}$ :Ca ratios of otoliths may help in determining whether or not individual eels actually enter into freshwater at the elver stage and whether they remain in freshwater, estuarine or marine environments until the silver eel stage, and also whether they move between different habitats with differing salinity regimes.

Otolith microchemistry studies have revealed that some yellow and silver eels of northern temperate Anguilla anguilla and A. japonica never migrate into freshwater, but spend their entire life in the ocean (Tsukamoto et al. 1998). Furthermore, application of otolith $\mathrm{Sr}$ :Ca ratios to trace the migratory history of eels revealed otolith signatures that were intermediate to those of marine and freshwater residents of $A$. anguilla (Tzeng et al. 1997, 2000), A. japonica (Tsukamoto \& Arai 2001, Tzeng et al. 2002, Arai et al. 2003) and A. rostrata (Jessop et al. 2002), and appeared to reflect estuarine residence, or show clear evidence of switching between different salinity environments. It thus appears that a proportion of eels move frequently between different environments during their growth phase. Therefore, because the individuals of several anguillid species have been found to remain in estuarine or marine habitats, it appears that anguillid eels do not all enter into freshwater environments, and these species have been suggested to display more of an apparent facultative catadromy (Tsukamoto \& Arai 2001).

Although $\mathrm{Sr}: \mathrm{Ca}$ ratios have been studied in the otoliths of yellow and silver eels of the 3 species of northern temperate anguillid eels, there have been no studies of this nature on southern hemisphere species. Therefore it is not known if the southern temperate species display the same tendency to utilize both estuarine and marine environments in addition to the typical freshwater environments. To begin to address this question, we analyzed the $\mathrm{Sr}$ :Ca ratios in the otoliths of silver eels of Anguilla dieffenbachii and A. australis that were caught in Lake Ellesmere on the east coast of the South Island of New Zealand, which is a shallow lagoon with a variety of salinities (Gerbeaux 1993). This lake has freshwater inputs from a river and several small streams and is separated from the ocean by a narrow gravel spit that is periodically artificially opened to the ocean. During these openings, saltwater enters the lake and results in an estuarine-like environment. Therefore, this lake provides a unique opportunity to study the age, growth, habitat use, and movements of 2 species of anguillid eel using otolith microchemistry, and to compare these data to the findings of other recent studies of eels in Lake Ellesmere (Jellyman et al. 1996, Jellyman \& Todd 1998, Jellyman \& Chisnal 1999, Jellyman 2001).

The objective of this study was to use $\mathrm{Sr}$ :Ca ratios to reconstruct the environmental history of the eels captured in Lake Ellesmere to determine the salinity environments that each individual of the 2 species had experienced, and to compare these data with the age and growth of each eel. This approach enabled the biological characteristics and apparent habitat use of the 2 species and sexes to be compared, and provides a chance to begin to assess whether plasticity in freshwater entry is ubiquitous among temperate eels.

\section{MATERIALS AND METHODS}

Study site. Lake Ellesmere is New Zealand's 4thlargest lake $\left(180 \mathrm{~km}^{2}\right)$ and is a shallow and productive coastal lake/lagoon in Canterbury, South Island, New Zealand (Fig. 1). The lake has maximum depths of ca. 2.0 to $3.1 \mathrm{~m}$ that vary depending on the water level in the lake, which ranges from 0.4 to $1.5 \mathrm{~m}$ above mean sea level (Irwin \& Main 1989). This unusual lake is only separated from the Pacific Ocean by a narrow gravel 


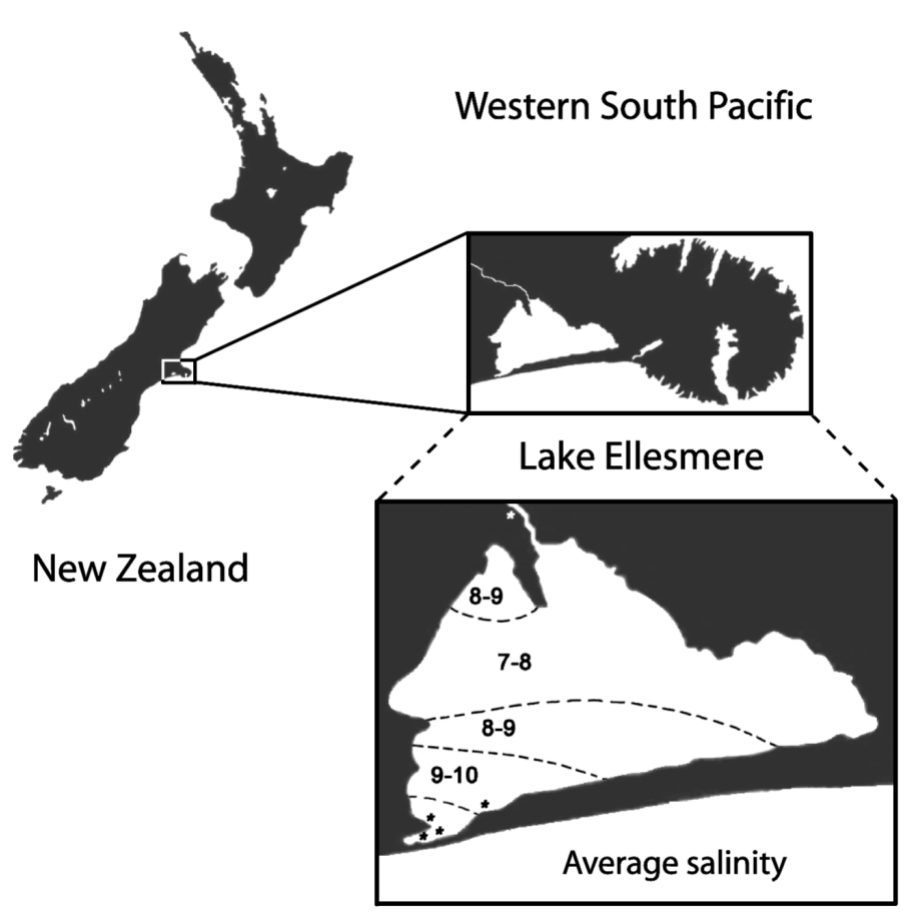

Fig. 1. Location of Lake Ellesmere in New Zealand, with 2 insets showing the location of the lake at the southern edge of the Banks Peninsula (top inset) and average values of salinity from 1979 to 1980 (bottom inset; adapted from Lineham 1983). The Selwyn River is the largest tributary of the lake and is shown entering the northern part. Approximate locations where silver eels were collected are shown with small stars

bank of 100 to $200 \mathrm{~m}$ width at its narrowest point, and it has a relatively high salinity at the lake's southern end due to seepage or openings to the ocean. From as early as 1852, rising water levels during winter have prompted the construction of periodic artificial lake openings to allow additional drainage and prevent flooding of surrounding areas, and between 1945 and 1993 Lake Ellesmere has been open to the sea for an average of $79 \mathrm{~d} \mathrm{yr}^{-1}$. Openings (up to $7 \mathrm{yr}^{-1}$; Reid \& Holmes 1996) normally occur somewhere between late autumn and early winter and allow entry of seawater during high tide (e.g. Hughes et al. 1974). Accordingly, salinity is highly variable between locations, seasons and depths (Hughes et al. 1974, Gerbeaux 1993), probably varying from 0 ppt near river inflows, to fullstrength seawater near the lake opening site during some openings or storm events, when waves from the ocean crash over the bank. The mean monthly freshwater inflow is estimated to range from 6.4 (February) to 21.4 (August) $\mathrm{m}^{3} \mathrm{~s}^{-1}$ (Horrell 1992), with the Selwyn River being the largest tributary of the lake, and this input typically results in a salinity gradient within the lake (Fig. 1). The dominant substrates with the lake are soft mud and sand. Recruitment of eels occurs when lake openings coincide with the arrival of glass eels during spring (Jellyman \& Chisnall 1999) and the lake supports a substantial commercial fishery using fyke nets that primarily catch Anguilla australis (Jellyman \& Todd 1998).

Fish. Eels (358 to $1395 \mathrm{~cm}$ total length [TL], 61 to $8945 \mathrm{~g}$ body weight) were trapped by fyke nets around the time of new moon in March and April of 1992 and 1993 (Table 1) and were identified to species, sex and life history stage as described by Lokman et al. (1998). This time period coincides with the typical spawning migration season (Cairns 1941, Todd 1981), and the eels were caught primarily near the outlet area of the lake, with 39 being caught at the 4 sites near the outlet and 1 (Individual LF121) being caught in the Selwyn River (Fig. 1). During the migratory season, eels are probably easy to catch near the outlet, because when Lake Ellesmere is blocked off from the ocean during this time, silver eels have historically been observed to move ceaselessly back and forth along the shore of the gravel bank, and some would actually wriggle out of the water and cross the bank and make it into the ocean (Cairns 1941). During the present study, a total of 40 silver eels, consisting of 6 male and 14 female Anguilla australis, and 11 male and 9 female $A$. dieffenbachii, were used (Table 1). Physiological data from these individuals have been previously published (Lokman et al. 1998).

Otolith preparation and microchemical analysis. Sagittal otoliths were extracted from each fish, embedded in epoxy resin (Struers, Epofix) and mounted on glass slides. The otoliths were then ground and polished, as described by Arai et al. (1997, 2003). They were then cleaned in an ultrasonic bath and rinsed with deionized water prior to being examined.

For electron microprobe analyses, all otoliths were Pt-Pd coated by a high vacuum evaporator. Otoliths from 40 specimens (20 specimens in each species) were used for 'life-history transect' analysis of $\mathrm{Sr}$ and Ca concentrations, which were measured along a line down the longest axis of each otolith from the core to the edge using a wavelength dispersive X-ray electron microprobe (JEOL JXA-8900R), as described in Arai et al. $(1997,2001)$. Calcite $\left(\mathrm{CaCO}_{3}\right)$ and strontianite $\left(\mathrm{SrCO}_{3}\right)$ were used as standards. The accelerating voltage and beam current were $15 \mathrm{kV}$ and $1.2 \times 10^{-8} \mathrm{~A}$, respectively. The electron beam was focused on a point measuring $10 \mu \mathrm{m}$ in diameter, with measurements spaced at $10 \mu \mathrm{m}$ intervals.

'X-ray intensity maps' of both elements were made using a JEOL JXA-8900R electron probe microanalyzer as described by Tsukamoto \& Arai (2001) and Arai et al. (2003). The beam current was $0.5 \mu \mathrm{A}$, counting time was $0.1 \mathrm{~s}$, pixel size was $3 \times 3 \mu \mathrm{m}$, the electron beam was focused on a point of $1 \mu \mathrm{m}$ diameter, and other analytical conditions followed those for the life-history transect 
Table 1. Anguilla australis and A. dieffenbachii. Details of silver stage eels used for otolith microchemistry analyses. $\sigma^{\prime}:$ male, ọ: female

\begin{tabular}{|c|c|c|c|c|c|c|}
\hline Individual & $\begin{array}{c}\text { Total } \\
\text { length }(\mathrm{mm})\end{array}$ & $\begin{array}{c}\text { Body } \\
\text { weight (g) }\end{array}$ & Sex & $\begin{array}{l}\text { Age } \\
\text { (yr) }\end{array}$ & $\begin{array}{l}\text { Growth rate } \\
\left(\mathrm{mm} \mathrm{yr}^{-1}\right)\end{array}$ & $\begin{array}{c}\text { Average } \mathrm{Sr}: \mathrm{Ca} \\
\text { ratio }(\times 1000)\end{array}$ \\
\hline \multicolumn{7}{|c|}{ Anguilla australis } \\
\hline SF108 & 411 & 129 & $0^{11}$ & $13+$ & 27.1 & 5.75 \\
\hline SF109 & 405 & 113 & $0^{1}$ & $24+$ & 14.4 & 6.51 \\
\hline SF112 & 358 & 78 & $0^{7}$ & $13+$ & 23.0 & 6.30 \\
\hline SF114 & 362 & 61 & $0^{11}$ & $19+$ & 15.9 & 6.29 \\
\hline SF151 & 380 & 110 & $0^{1}$ & $13+$ & 24.7 & 5.54 \\
\hline SF152 & 371 & 86 & $0^{7}$ & $14+$ & 22.3 & 6.29 \\
\hline SF121 & 685 & 800 & ○ & $27+$ & 23.2 & 5.39 \\
\hline SF122 & 984 & 1836 & $\begin{array}{l}7 \\
0\end{array}$ & $33+$ & 28.0 & 2.46 \\
\hline SF123 & 1035 & 2492 & $\begin{array}{l}q \\
\wp\end{array}$ & $23+$ & 42.4 & 6.15 \\
\hline SF124 & 766 & 1220 & @ & $21+$ & 33.7 & 6.08 \\
\hline SF125 & 853 & 1588 & o & $27+$ & 29.4 & 6.27 \\
\hline SF126 & 701 & 800 & o & $28+$ & 22.9 & 3.48 \\
\hline SF127 & 668 & 636 & $\begin{array}{l}7 \\
\text { o } \\
\text { o }\end{array}$ & $25+$ & 24.3 & 2.31 \\
\hline SF129 & 824 & 1142 & $\begin{array}{l}f \\
\wp\end{array}$ & $29+$ & 26.4 & 2.97 \\
\hline SF130 & 865 & 1182 & $\begin{array}{l}7 \\
\text { 舟 }\end{array}$ & $21+$ & 38.4 & 1.83 \\
\hline SF132 & 908 & 1980 & $\begin{array}{l}7 \\
\text { ○ }\end{array}$ & $15+$ & 56.6 & 7.35 \\
\hline SF134 & 946 & 2100 & 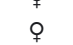 & $18+$ & 49.3 & 6.49 \\
\hline SF135 & 822 & 1175 & $\begin{array}{l}7 \\
\text { o } \\
\text { o }\end{array}$ & $22+$ & 34.7 & 3.18 \\
\hline SF139 & 665 & 656 & 表 & $27+$ & 22.4 & 2.26 \\
\hline SF140 & 799 & 1092 & $\begin{array}{l}\uparrow \\
\wp\end{array}$ & $31+$ & 23.9 & 2.48 \\
\hline \multicolumn{7}{|c|}{ Anguilla dieffenbachii } \\
\hline LF102 & 621 & 567 & $0^{11}$ & $36+$ & 15.4 & 3.52 \\
\hline LF103 & 605 & 494 & $0^{11}$ & $40+$ & 13.5 & 2.20 \\
\hline LF104 & 607 & 558 & $0^{1}$ & $15+$ & 36.0 & 1.87 \\
\hline LF105 & 620 & 588 & $0^{17}$ & $23+$ & 24.1 & 4.02 \\
\hline LF106 & 614 & 584 & $0^{17}$ & $22+$ & 24.9 & 2.13 \\
\hline LF107 & 677 & 771 & $0^{7}$ & $34+$ & 17.9 & 1.86 \\
\hline LF108 & 671 & 764 & $0^{1}$ & $25+$ & 24.2 & 3.56 \\
\hline LF109 & 574 & 413 & $0^{7}$ & $16+$ & 31.7 & 2.62 \\
\hline LF111 & 619 & 489 & $0^{1}$ & $34+$ & 16.2 & 1.87 \\
\hline LF112 & 672 & 656 & $0^{7}$ & $22+$ & 27.5 & 3.32 \\
\hline LF113 & 611 & 548 & $0^{11}$ & $19+$ & 28.6 & 1.95 \\
\hline LF121 & 1250 & 5690 & 웅 & $43+$ & 27.5 & 2.09 \\
\hline LF123 & 1210 & 5400 & $\begin{array}{l}7 \\
\text { ధ }\end{array}$ & $46+$ & 24.9 & 2.58 \\
\hline LF124 & 1395 & 8945 & @ & $44+$ & 30.2 & 2.35 \\
\hline LF125 & 1360 & 7225 & ○ & $46+$ & 28.1 & 2.25 \\
\hline LF126 & 1095 & 4028 & $\begin{array}{l}\uparrow \\
\wp\end{array}$ & $23+$ & 44.7 & 3.82 \\
\hline LF127 & 1197 & 4684 & $\begin{array}{l}7 \\
\text { ○ }\end{array}$ & $38+$ & 29.7 & 2.26 \\
\hline LF129 & 1263 & 5380 & $\begin{array}{l}7 \\
\text { ధ }\end{array}$ & $34+$ & 35.2 & 1.82 \\
\hline LF131 & 1208 & 5140 & $\begin{array}{l}7 \\
\text { o }\end{array}$ & $59+$ & 19.3 & 2.19 \\
\hline LF132 & 1300 & 6000 & $\begin{array}{l}7 \\
0\end{array}$ & $41+$ & 30.1 & 3.48 \\
\hline
\end{tabular}

analyses. Otoliths of 14 of the specimens used for the lifehistory transects ( 7 specimens in each species) were also used in the X-ray intensity map analyses.

Age estimation and data analysis. Following the microchemistry analyses, the otoliths were repolished to remove the coating. Otoliths were then etched with $1 \% \mathrm{HCl}$ for $60 \mathrm{~s}$, stained with $1 \%$ toluidine blue and aged by counting the number of blue-stained transparent zones (Fig. 2), as reported in Graynoth (1999) and Arai et al. (2003). The ages given in this study are up to the last annuli and don't include any additional daily age of less than $1 \mathrm{yr}$. The annual deposition of these annuli have been validated to be deposited annually for both Anguilla australis and A. dieffenbachii (Chisnal \& Kalish 1993, see Graynoth 1999).

Mean annual growth rates were calculated by dividing the TL of individuals minus $59.3 \mathrm{~mm}$ in Anguilla australis (Arai et al. 1999) and $66.8 \mathrm{~mm}$ in A. dieffenbachii (Marui et al. 2001), which are the mean sizes of the glass eels of these 2 species when they recruit to the New Zealand coasts. We calculated the average $\mathrm{Sr}$ :Ca ratios for the values outside the elver mark to enable comparisons to the conventional criteria of Tsukamoto \& Arai (2001), which categorized speci- 


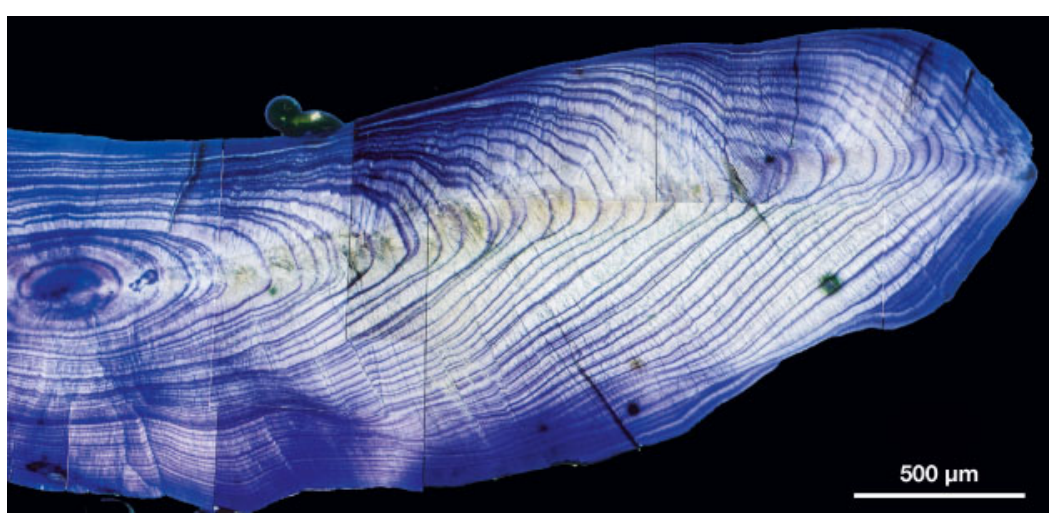

Fig. 2. Anguilla dieffenbachii. Light microscope photograph showing the microstructure of an otolith stained with toluidine blue, from a $38 \mathrm{yr}$ old, $1197 \mathrm{~mm}$ total length female silver eel (Individual LF127) caught in Lake Ellesmere, New Zealand

mens into 'sea eels' ( $\mathrm{Sr}$ :Ca ratios $>6.0 \times 10^{-3}$ ), 'estuarine eels' (Sr:Ca ratios 2.5 to $6.0 \times 10^{-3}$ ) or 'river eels' (Sr:Ca ratios $\left.<2.5 \times 10^{-3}\right)$.

\section{RESULTS}

\section{Biological characteristics}

The total lengths of the silver eels of Anguilla australis ranged from 362 to $411 \mathrm{~mm}$ with a mean $\pm \mathrm{SD}$ of $381 \pm 22.2 \mathrm{~mm}$ for males, and ranged from 668 to $1035 \mathrm{~mm}$ with a mean of $823 \pm 118.5 \mathrm{~mm}$ for females (Table 1, Fig. 3). The total lengths of the silver eels of A. dieffenbachii were somewhat larger, and ranged from 574 to $672 \mathrm{~mm}$ with a mean of $626 \pm 32.7 \mathrm{~mm}$ for males, and from 1197 to $1395 \mathrm{~mm}$ with a mean of $1253 \pm 90.8 \mathrm{~mm}$ for females. There were significant differences in the total lengths between the sexes within both species (Mann-Whitney $U$-test, $\mathrm{df}=18, \mathrm{p}<0.0005$ ) and between the males ( $\mathrm{df}=15, \mathrm{p}<0.001)$ and females $(\mathrm{df}=21, \mathrm{p}<0.0001)$ between the 2 species.

The body weights of the silver eels of Anguilla australis ranged from 362 to $411 \mathrm{~g}$ with a mean $\pm \mathrm{SD}$ of $381 \pm 22.2 \mathrm{~g}$ for males, and from 668 to $1035 \mathrm{~g}$ with a mean of $823 \pm 118.5 \mathrm{~g}$ for females (Table 1 ). The body weights of the silver eels of $A$. dieffenbachii were also larger, ranged from 574 to $672 \mathrm{~g}$ with a mean of $626 \pm$ $32.7 \mathrm{~g}$ for males, and from 1197 to $1395 \mathrm{~g}$ with a mean of $1253 \pm 90.8 \mathrm{~g}$ for females. There were significant differences in the body weights between the sexes within both species (Mann-Whitney $U$-test, $\mathrm{df}=18, \mathrm{p}<$ $0.0005)$ and between the males $(\mathrm{df}=15, \mathrm{p}<0.001)$ and females ( $\mathrm{df}=21, \mathrm{p}<0.0001)$ between the 2 species.

The ages of Anguilla australis silver eels, based on the number of annual rings in their otoliths, ranged from 13 to 24 yr with a mean \pm SD of 16 $\pm 4.6 \mathrm{yr}$ for males, and from 15 to 33 with a mean of $25 \pm 5.0 \mathrm{yr}$ for females. The ages of $A$. dieffenbachii silver eels ranged from 15 to $40 \mathrm{yr}$ with a mean \pm $\mathrm{SD}$ of $26 \pm 8.6 \mathrm{yr}$ for males, and from 23 to $59 \mathrm{yr}$ with a mean of $42 \pm 9.8 \mathrm{yr}$ for females (Table 1, Fig. 3). The ages of the male silver eels were younger on average than the females and they were significantly different within both species (Mann-Whitney $U$-test, df $=18, \mathrm{p}<0.005)$. The ages of each of the 2 sexes were also different between the 2 species (males, $\mathrm{df}=15, \mathrm{p}<0.05$; females, $d f=21, p<0.001$ ). Because of such a narrow range of sizes, no relationship was found between age and total length within the sex of each species $\left(\mathrm{r}^{2}=0.05\right.$ to 0.16 , regression not shown)

The somatic growth rates of the Anguilla australis silver eels ranged from 14.4 to $24.7 \mathrm{~mm} \mathrm{yr}^{-1}$, with a mean $\pm \mathrm{SD}$ of $21.2 \pm 5.0 \mathrm{~mm} \mathrm{yr}^{-1}$ for males, and ranged from 22.4 to $56.6 \mathrm{~mm} \mathrm{yr}^{-1}$ with a mean of $32.5 \pm 10.7 \mathrm{~mm} \mathrm{yr}^{-1}$ for females (Table 1, Fig. 4). The growth rates of $A$. dieffenbachii ranged from 15.4 to $36.0 \mathrm{~mm} \mathrm{yr}^{-1}$ with a

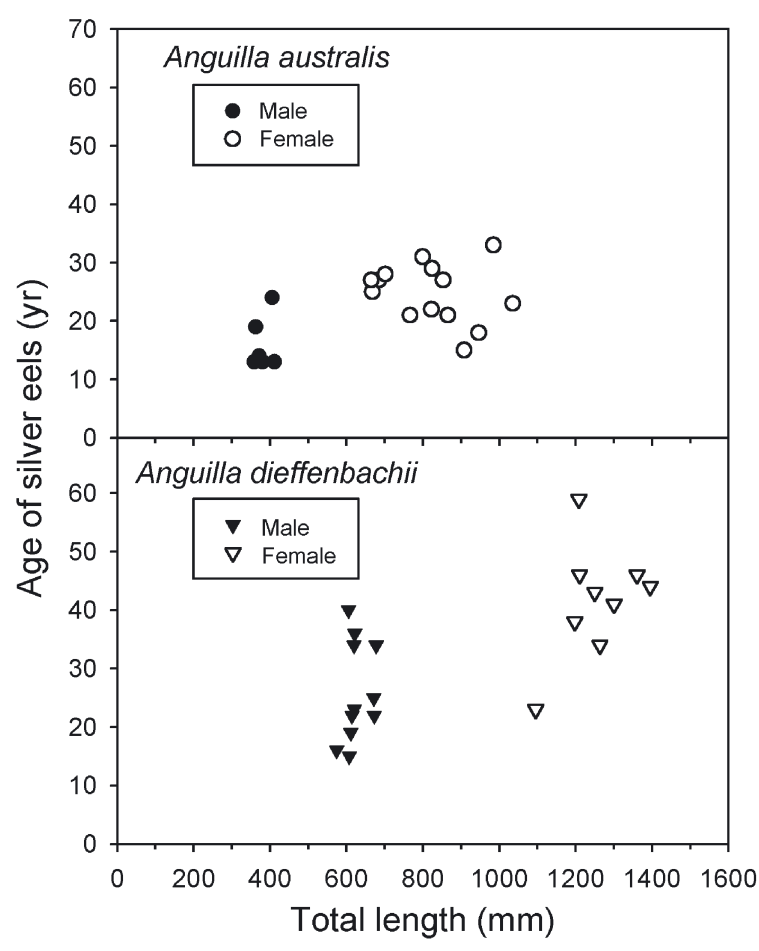

Fig. 3. Anguilla australis and A. dieffenbachii. Total lengths versus total age in years of the silver eels caught in Lake Ellesmere and used in the otolith microchemistry analyses of this study 


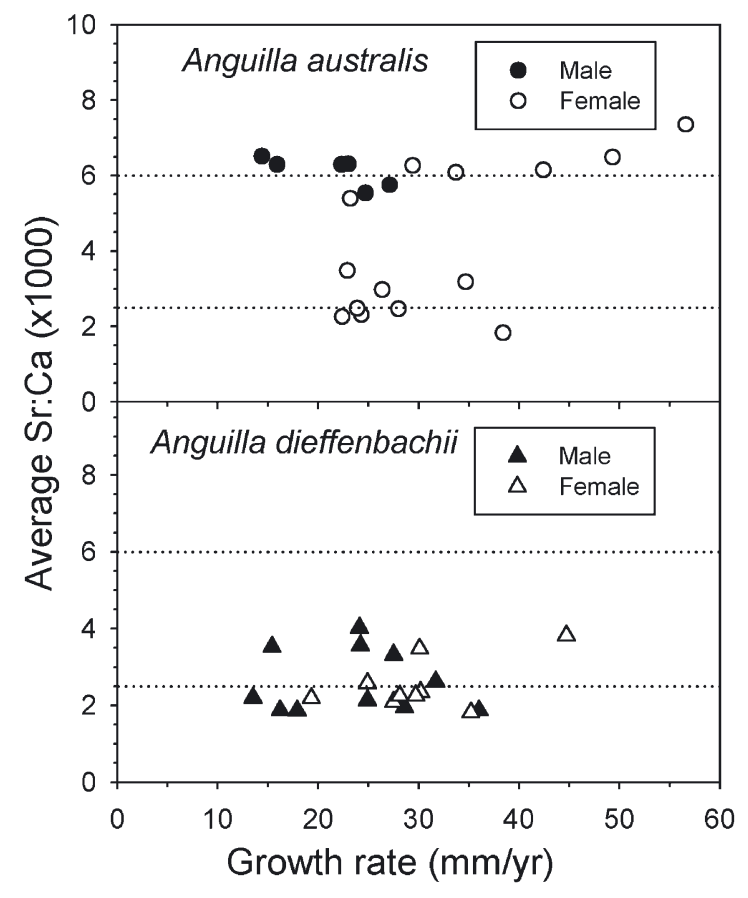

Fig. 4. Anguilla australis and A. dieffenbachii. Growth rate versus the average $\mathrm{Sr}$ :Ca ratio outside the elver mark in the otoliths of the silver eels caught in Lake Ellesmere. Dotted lines show estimated average $\mathrm{Sr}: \mathrm{Ca}$ ratios that Tsukamoto \& Arai (2001) used to roughly categorize the different habitat use patterns of eels as 'sea eels' $\left(\mathrm{Sr}\right.$ :Ca ratios $\left.>6.0 \times 10^{-3}\right)$, 'estuarine eels' (Sr:Ca ratios 2.5 to $6.0 \times 10^{-3}$ ) or 'river eels' (Sr:Ca ratios $<2.5 \times 10^{-3}$ ) mean of $23.6 \pm 7.2 \mathrm{~mm} \mathrm{yr}^{-1}$ for males, and ranged from 19.3 to $35.2 \mathrm{~mm} \mathrm{yr}^{-1}$ with a mean of $30.0 \pm 7.0 \mathrm{~mm} \mathrm{yr}^{-1}$ for females. Although a significant difference in growth rate was found between the sexes in $A$. australis (Mann-Whitney $U$-test, $\mathrm{df}=18, \mathrm{p}<0.05$ ), there were no significant differences between the sexes in A. dieffenbachii or between each of the 2 sexes of $A$. australis and A. dieffenbachii ( $\mathrm{df}=15$ to $21, \mathrm{p}>0.05)$.

\section{Otolith microchemistry}

The X-ray intensity maps showed that the Sr contents of the otoliths were remarkably variable among the silver eels that were examined (Fig. 5). All the otoliths had a high Sr area at their center (red oval spot; diameter ca. 250 to $350 \mu \mathrm{m}$ in the long axis) that was surrounded by an elver mark, which could be observed with a light microscope. This 'high Sr core' was considered to correspond to the oceanic leptocephalus stage up to the early glass-eel stage just after metamorphosis, which would be the part of the life history from the spawning area to coastal waters (Otake et al. 1994, Arai et al. 1997, 1999). Four of the 14 specimens of Anguilla australis were characterized by a consistent light yellowish-blue color (medium Sr concentration) from the otolith core to the edge (Fig. 5; Individual SF114). Four of the 14 specimens (2 specimens in each species) showed a wide space of yellowish color

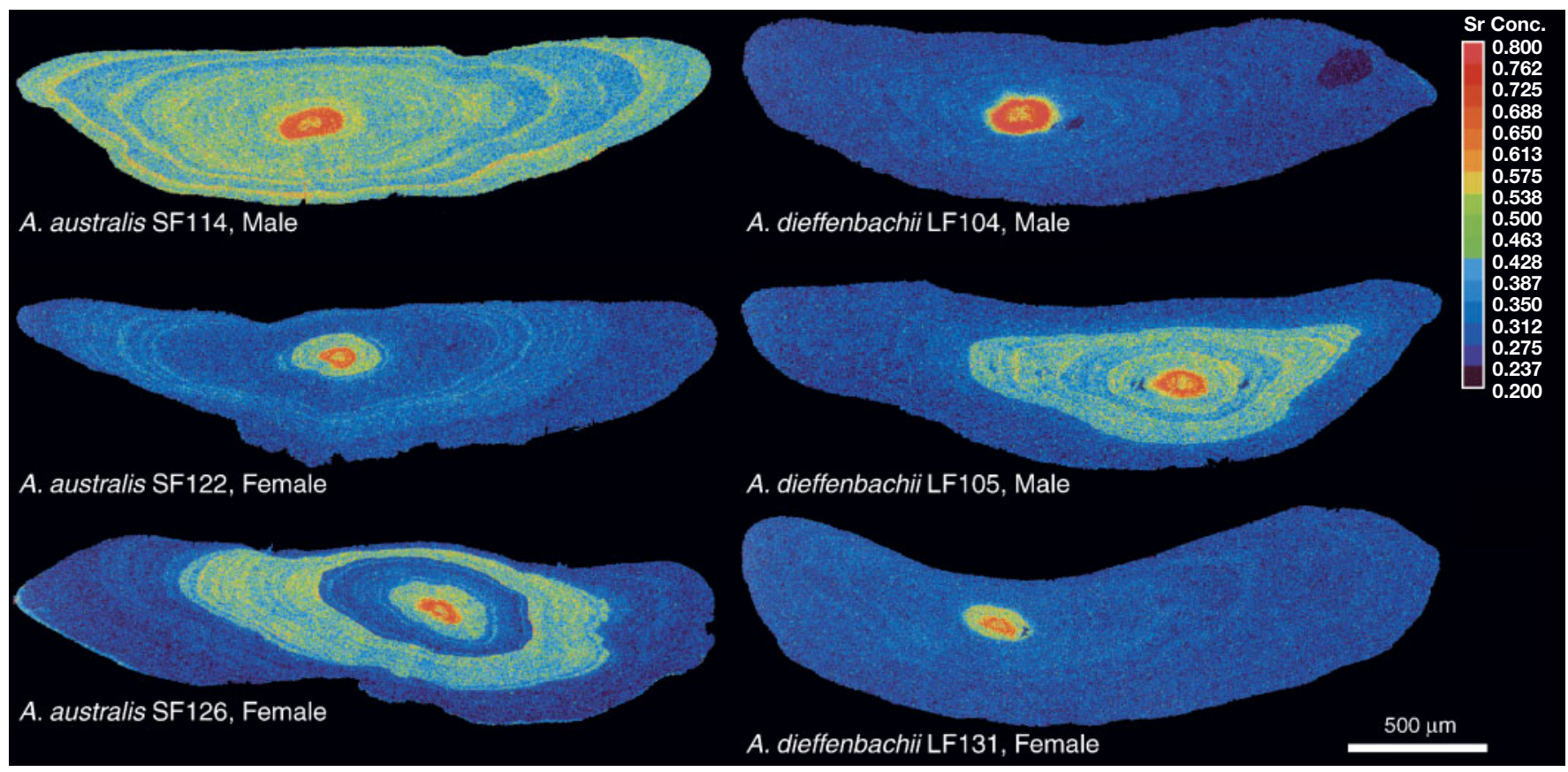

Fig. 5. Anguilla australis and A. dieffenbachii. 2D images made using X-ray electron microprobe analysis of the Sr concentration in the otoliths. Both eel species collected in Lake Ellesmere, New Zealand. Sr concentrations are represented by 16 colors from red (highest), to yellow, to green, to blue (lowest), shown in the scale. Specimen numbers correspond to those listed in Table 1 
(high Sr) just outside the high Sr core that was surrounded by uniformly low Sr concentrations (Fig. 5; Individual LF105), or displayed several changes from low to high Sr concentrations (Fig. 5; Individual SF126). The other specimens showed a uniformly low Sr concentration over the whole otolith (blue color), except for the high Sr core (Fig. 5; Individuals SF122, LF104, LF131).

The Sr:Ca ratios in the transects along the radius of each otolith showed the same common feature of a high ratio near the center of the otolith in all specimens of both Anguilla australis and A. dieffenbachii, but there were generally 3 different patterns outside the otolith core (Figs. $6 \&$ 7). All otolith specimens had a central core region with high $\mathrm{Sr}$ :Ca ratios (14.9 to $20.7 \times 10^{-3}$ in A. australis, 14.4 to $19.6 \times 10^{-3}$ in A. dieffenbachii) (Figs. $6 \&$ 7) surrounded by an elver mark that could be observed with a light microscope. The radius of the elver mark in $A$. australis ranged from 141.6 to $172.7 \mu \mathrm{m}$ with a mean $\pm \mathrm{SD}$ of $155.5 \pm 8.5 \mu \mathrm{m}$, and in A. dieffenbachii it ranged from 142.9 to $171.9 \mu \mathrm{m}$ with a mean of $153.1 \pm 7.3 \mu \mathrm{m}$. The high $\mathrm{Sr}$ :Ca ratios in the central core region during the leptocephalus stage may be derived from the large amounts of gelatinous extracellular matrix that fill their bodies until metamorphosis (Otake et al. 1994). This material is composed of sulfated glycosaminoglycans (GAG), which are converted into other compounds during metamorphosis (Pfeiler 1984). The drastic decrease in Sr at the outer region in both river and seawater samples after metamorphosis to glass eels may occur because these sulfated polysaccharides have an affinity to alkali earth elements, and are particularly high in Sr, suggesting that a high $\mathrm{Sr}$ content in the body has a significant influence on otolith $\mathrm{Sr}$ content through saccular epithelium in the inner ear, and the sudden loss of Sr-rich GAG during metamorphosis probably results in the lower Sr concentration in otoliths after metamorphosis (Otake et al. 1994). Outside of the high Sr core, there was considerable variation in the $\mathrm{Sr}$ : Ca ratios in the otoliths of some of the eels of both species.

In Anguilla australis, the change in Sr:Ca values outside the elver mark was generally divided into 3 types (Fig. 6): (1) constantly low values generally ranging between ca. 1.83 and $2.48 \times 10^{-3}$ (mean: $2.27 \pm 0.26$ ),
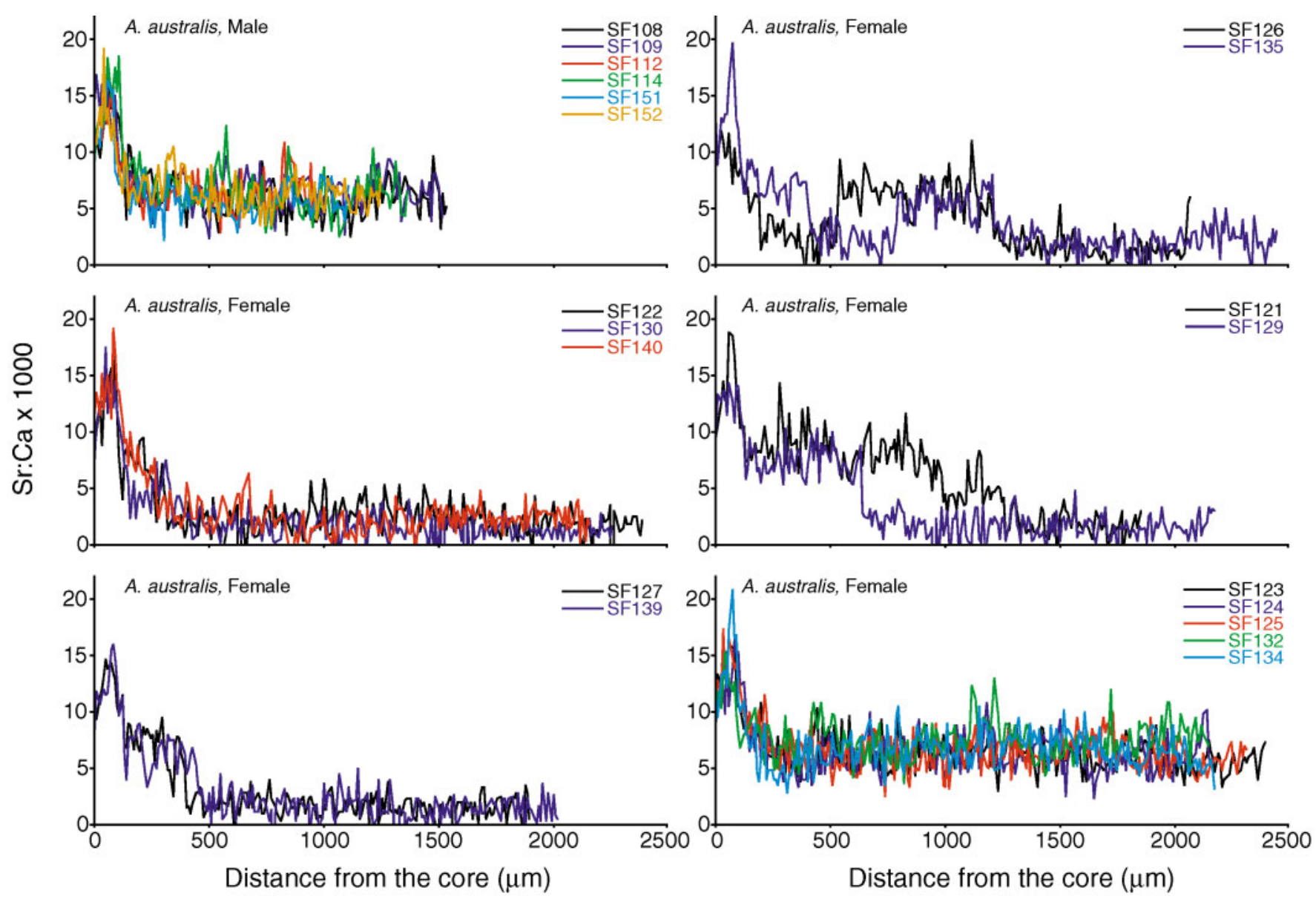

Fig. 6. Anguilla australis. Sr:Ca ratios in otoliths of silver eels measured along line transects from the core ( $0 \mu \mathrm{m})$ to the edge of the otoliths of all specimens collected in Lake Ellesmere. Specimen numbers correspond to those listed in Table 1 

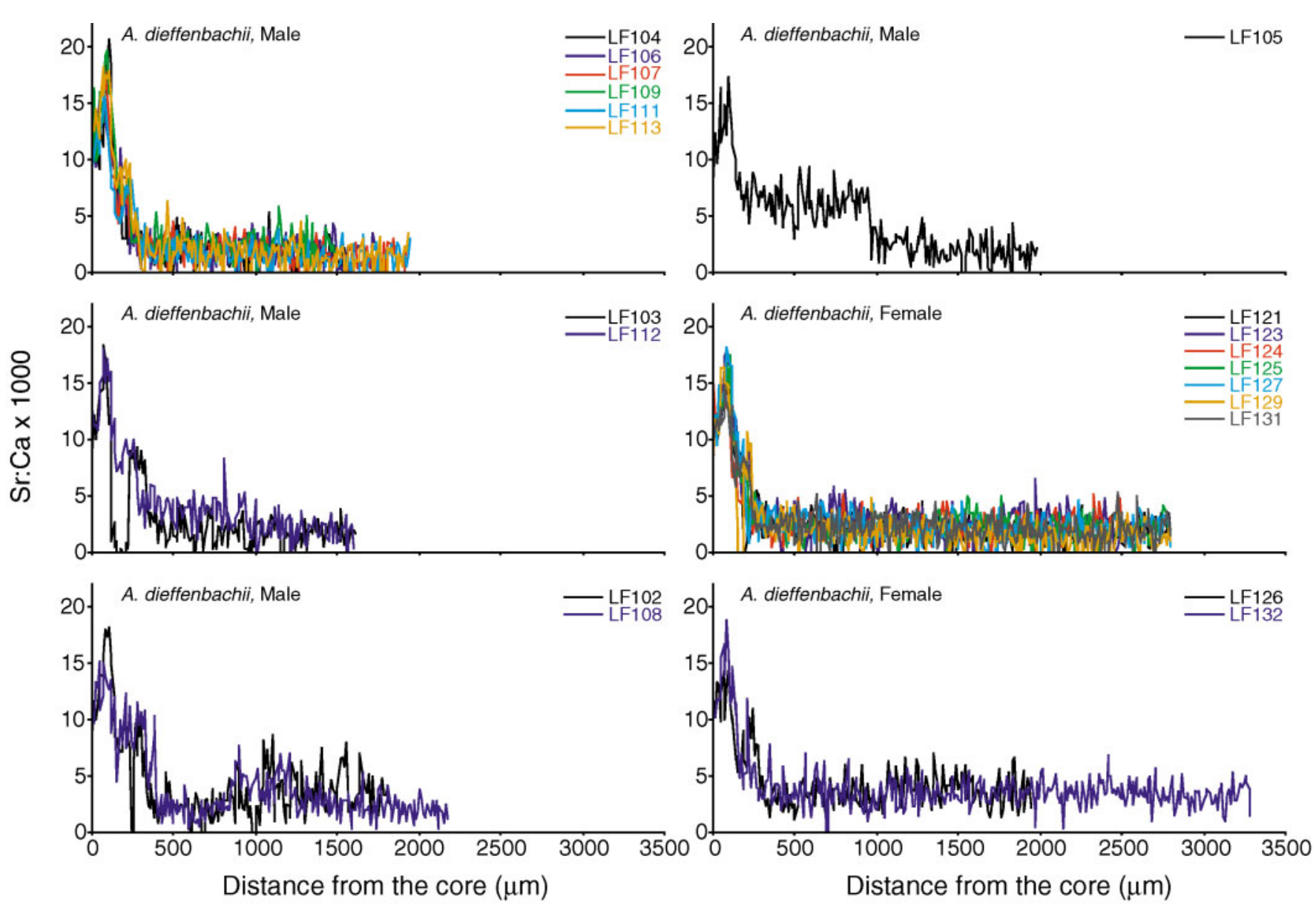

Fig. 7. Anguilla dieffenbachii. Sr:Ca ratios in otoliths of silver eels measured along line transects from the core ( $0 \mu \mathrm{m})$ to the edge of the otoliths of all specimens collected in Lake Ellesmere. Specimen numbers correspond to those listed in Table 1

(2) relatively high values generally ranging between ca. 6.08 and $7.35 \times 10^{-3}$ (mean: $6.41 \pm 0.38$ ), but larger than $5 \times 10^{-3}$ with no apparent movement into freshwater, and (3) values that change between high and low values at various distances outside the elver mark within an overall range of 2.97 to $5.75 \times 10^{-3}$ (mean: $4.38 \pm 1.30$ ), with either single or multiple movements from one salinity habitat to another. The most interesting individual of this type (Individual SF126, age $=27$ yr) apparently lived in freshwater, then in relatively high salinity before returning again to freshwater. The marked contrast in levels of $\mathrm{Sr}$ in the otolith of this specimen can clearly be seen in both the otolith image (Fig. 5) and the life-history transect (Fig. 6). There were 3 of the 20 females of $A$. australis that showed the Type 1 pattern of low Sr:Ca values in their otoliths, which is apparently indicative of long-term residence in freshwater habitats after upstream migration during the elver stage. Two others showed evidence that they remained in areas with relatively high salinity for a few years before entering freshwater. However, none of the males of this species showed evidence of freshwater use, and all either had the constantly high values of Type 2 or had the variable Type 3 values, indicating that they had experienced salinity during their growth phase.

In Anguilla dieffenbachii, the temporal changes in otolith $\mathrm{Sr}: \mathrm{Ca}$ ratios outside the high $\mathrm{Sr}$ :Ca center (Fig. 5) were roughly divided into the same 2 patterns of Types 1 and 3 found in A. australis, but there were 2 other female specimens (Individuals LF126 and LF132) that showed relatively constant intermediate values ranging from 3.48 to $3.82 \times 10^{-3}$ (mean: $3.65 \pm 0.24$ ) and 1 male (Individual LF112, $3.32 \times 10^{-3}$ ) that did not fit the 3 general categories designated for $A$. australis. The $A$. dieffenbachii specimens showing the Type 1 pattern had consistently low $\mathrm{Sr}$ :Ca ratio values generally ranging between ca. 1.82 and $2.35 \times 10^{-3}$ (mean: $2.07 \pm 0.19$ ) (Fig. 7), suggesting freshwater residency. The LF121 female was the only eel that was captured in the Selwyn River and it was among those that showed the consistently low $\mathrm{Sr}$ Ca ratios in the line 
transects (Fig. 5), suggesting that at least some of these eels had migrated from the freshwater reaches of the river. Specimens exhibiting the Type 3 pattern had values that varied between high and low levels, and 1 male (Individual LF105) showed a sudden switch from high to low values, indicative of a single movement between markedly different salinity levels.

To evaluate the general habitat use of each specimen based on their otolith $\mathrm{Sr}$ :Ca ratios in relation to their growth rates, and to enable direct comparisons to previous studies on temperate anguillid species, the mean of the Sr:Ca ratios outside the elver mark was calculated for each specimen (Fig. 4). Since all specimens had experienced the same common oceanic life as a preleptocephalus, leptocephalus, metamorphosing larva, and early glass eel, the Sr:Ca ratios inside the elver mark could be excluded from this mean value (Figs. 6 \& 7), according to Tsukamoto \& Arai (2001). In Anguilla australis, the mean $\mathrm{Sr}: \mathrm{Ca}$ ratios outside the elver mark ranged from $1.8 \times 10^{-3}$ to $7.4 \times 10^{-3}$, but these values showed 2 separate distributions of values corresponding to the traces in the Type 1 and Type 2 and 3 line transects, respectively (Figs. $6 \&$ 7). The 3 females (Individuals SF126, SF129, and SF135) with slightly higher values than the Type 1 fish that were around $3 \times 10^{-3}$ were the ones that had changing ratio levels in their life history transects (Fig. 6). However, in A. dieffenbachii, there were not 2 distinctly separate distributions of mean $\mathrm{Sr}$ :Ca ratios because there were only the Type 1 patterns $\left(1.8\right.$ to $\left.2.6 \times 10^{-3}\right)$ or 6 specimens (3.3 to $\left.4.0 \times 10^{-3}\right)$ that had either intermediate or changing values (Fig. 4). In total, $85 \%$ of the individuals of $A$. australis showed evidence of either experiencing relatively high salinities resulting in $\mathrm{Sr}: \mathrm{Ca}$ ratios levels at or close to that of sea eels throughout their growth phase, or experiencing relatively high salinities during only part of their life. However, only $30 \%$ of the individuals of $A$. dieffenbachii showed much indication of experiencing moderate or high salinities during their growth phase. There was no apparent relationship between the growth rates of the individuals of either species and the mean $\mathrm{Sr}$ :Ca ratios in their otoliths; however, individuals with the highest growth rates also had high Sr:Ca ratios (Fig. 4).

\section{DISCUSSION}

\section{Biological characteristics of silver eels}

Silver eels of Anguilla australis and A. dieffenbachii examined during this study showed the typical sexual dimorphism in size as other temperate anguillid species, and they were of the same general size as other silver eels that have been reported recently from near the outlet of the Lake Ellesmere and elsewhere in New Zealand. Female silver eels in this study were significantly larger than males for both $A$. australis and $A$. dieffenbachii, and this is typical for these 2 species (Todd 1980, Jellyman \& Todd 1998, Jellyman 2001) and for other temperate species such as A. rostrata (Helfman et al. 1987, Jessop 1987, Oliveira 1999), A. anguilla (Panfili et al. 1994, Poole \& Reynolds 1996), and A. japonica (Sasai et al. 2001). Jellyman \& Todd (1998) reported that the lengths of male silver eels of $A$. australis in Lake Ellesmere have been decreasing in the last 50 $\mathrm{yr}$, and the males collected for our study in 1992 and 1993 were the same size, ca. $400 \mathrm{~mm}$ TL (Fig. 3), as those they examined from 1993 to 1996. Female A. australis migrating from Lake Ellesmere, however, appear to have been getting longer in length in the last $20 \mathrm{yr}^{\text {, }}$ and those examined in this study were of the same size range $($ mean $=823 \mathrm{~mm}$ ) as those reported by Jellyman (2001) collected in 1998 (mean $=884 \mathrm{~mm}$ ). The length of male and female $A$. dieffenbachii silver eels in this study were also similar to those reported for migrants of this species in Lake Ellesmere and a tributary of the Waimakariri River in Canterbury, New Zealand (Burnet 1969, Todd 1980). Therefore, the eels examined for otolith microchemistry in this study appear to be the typical size of silver eels for these 2 species that migrate from Lake Ellesmere or other habitats in New Zealand.

The silver eels of Anguilla australis caught in Lake Ellesmere and examined for otolith microchemistry in this study had relatively similar ages and growth rates compared to previous studies on this species in the lake. The ages of the female $A$. australis silver eels in this study ranged from 15 to $33 \mathrm{yr}$ (mean $=25)$, which is somewhat older than the range of 9 to $25 \mathrm{yr}$ (mean = 19) observed by Jellyman (2001) in the lake. Almost all the male silver eels in Lake Ellesmere that were aged during 8 yr between 1975 and 1995 were found to range between 9 and $22 \mathrm{yr}$ of age (mean ca. $14 \mathrm{yr}$ ) when they begin to migrate (Jellyman \& Todd 1998), and this is quite similar to the males examined in this study, which were 13 to $24 \mathrm{yr}$ old (mean $=16)$. The growth rates of these males of 14 to $25 \mathrm{~mm} \mathrm{yr}^{-1}$ (mean $=21$ ) in this study were lower than those for the females, which were 22 to $56 \mathrm{~mm} \mathrm{yr}^{-1}$ (mean = 32). Similarly, the growth rates found by Jellyman (2001) for females of 23 to $93 \mathrm{~mm} \mathrm{yr}^{-1}$ (mean $=45$ ) were considerably higher than those found for males in Lake Ellesmere by Jellyman \& Todd (1998), which were 14 to $47 \mathrm{~mm} \mathrm{yr}^{-1}$ (mean $\left.=29\right)$. The differences between some of the ages or growth rates in this study and in previous studies may be due to the smaller sample sizes of silver eels that we examined, or to the changes in size, age and sex ratio that have been observed over many years in the lake (Jellyman \& Todd 1998, Jellyman 2001). 
Although their growth rates were relatively similar, the ages of the Anguilla dieffenbachii from Lake Ellesmere during this study were older than those of $A$. australis, and many of the silver eels of these 2 species in New Zealand appear to reach greater ages in some habitats than most other temperate anguillids. During this study the ages of male (15 to $40 \mathrm{yr}$, mean $=26$ ) and female $A$. dieffenbachii (23 to $59 \mathrm{yr}$, mean =42) overlapped considerably, as did their growth rates (13 to $37 \mathrm{~mm} \mathrm{yr}^{-1}$ for all eels except 1 female at $46 \mathrm{~mm} \mathrm{yr}^{-1}$ ). Many individuals of $A$. dieffenbachii have been found to reach ages of 30 to $50 \mathrm{yr}$ in streams and lakes in various areas of New Zealand, and even reach ages of as old as $90 \mathrm{yr}$ in at least one lake, which may have unusually slow growth rates (Chisnall \& Hicks 1993, Jellyman 1997). Most of the specimens of the 2 species we examined had growth rates within the same range (13 to $38 \mathrm{~mm} \mathrm{yr}^{-1}$ ), except for a few females that had considerably higher growth rates (42 to $56 \mathrm{~mm} \mathrm{yr}^{-1}$ ), and the average $\mathrm{Sr}$ :Ca values of these individuals were all within the higher range for each species (Fig. 4). Previous studies have clearly shown that there is considerable variation in the growth rates of these 2 species of eels in various habitats at a number of locations in New Zealand (Chisnall 1989, Chisnall \& Hicks 1993, Jellyman 1997), so based on the relatively small sample of this study, it is unclear if the growth rates of eels are typically higher in saline areas of Lake Ellesmere or not. What is evident, however, provided that these otolith age estimates are completely accurate in older eels (see Graynoth 1999), is that $A$. dieffenbachii, and to a lesser extent $A$. australis, appear to often reach ages of 30 to $50 \mathrm{yr}$ in Lake Ellesmere and many freshwater habitats in New Zealand (Jellyman 1997). These ages seem to be considerably older than the northern temperate anguillid species, whose maximum ages are typically less than 20 or 30 yr (Panfili et al. 1994, Poole \& Reynolds 1996, Olivera 1999, Aoyama \& Miller 2003).

\section{Habitat use and apparent movements}

Analyses of patterns of variation in the otoliths $\mathrm{Sr}: \mathrm{Ca}$ ratios from the Anguilla australis and A. dieffenbachii silver eels examined during this study indicated that a variety of environmental salinities had been experienced in the habitats that were occupied during the growth phase. Otolith microchemistry of these eels indicated that some of them had entered freshwater relatively quickly after recruitment and had stayed in freshwater until maturation, such as 14 of the $A$. dieffenbachii males and females and 3 of the $A$. australis females. Others, such as 6 A. australis males and 5 females, appeared to remain in relatively high salini- ties until maturation. In addition, a few individuals of both species showed evidence of shifts from one salinity level to another, and at least $2 \mathrm{~A}$. australis females showed clear evidence of 2 such shifts (Individuals SF126 and SF135, Fig. 6). This type of variability in otolith microchemistry and evidence of marine residency has also been found among A. japonica from various localities in Japanese coastal waters (Tsukamoto et al. 1998, Tsukamoto \& Arai 2001) and a river system in Taiwan (Tzeng et al. 2002). Otolith analyses of the yellow- and silver-eel stages of A. anguilla also have shown evidence of marine residency in the North Sea and Baltic Sea (Tsukamoto et al. 1998, Tzeng et al. 2000). Similarly, exclusive marine residency has been inferred for the American eel A. rostrata (Jessop et al. 2002).

In Lake Ellesmere, however, the ecological implications for habitat use are somewhat different than those in previous studies, because the lake is usually blocked off from the ocean by a narrow gravel bank. The variation in otolith microchemistry in the otoliths of the silver eels of this study suggest that there are some areas of the lake that consistently have relatively high levels of salinity. Some individuals of both species showed evidence of shifts in salinity and could have either moved within the lake or into one of the streams, or the salinity regime in the area of the lake they inhabited varied over time. It is likely that there is a consistently higher average salinity near the outlet (Fig. 1) due to seepage or lake openings, and salinity may be ca. 5 to 10 ppt most of the time or ca. 22 ppt near the bottom during lake openings or calm periods (Gerbeaux 1993), but even higher salinities could be present in some locations for short periods. However, if compared to data on Anguilla japonica (Tsukamoto \& Arai 2001), it appears that the 2 A. australis females (Individuals SF121 and SF129), which showed slightly higher Sr:Ca ratios than all the others during their early growth phase, had been either living in consistently high salinities near the outlet of the lake for a number of years, or they entered the lake during one of the openings and had previously been living in coastal waters as 'sea eels'.

Within the sample of eels examined here, both species appear to be able to inhabit high salinities, but the greater proportion of Anguilla australis eels that showed evidence of residence in the saline parts of the lake suggests that this may reflect a general difference in the patterns of habitat use of the 2 species. A. australis is apparently much more abundant in Lake Ellesmere, because the commercial fishery there harvests large quantities of that species, but $A$. dieffenbachii have become rare in recent years (Jellyman \& Todd 1998). In the Kakanui River estuary to the south of the Lake Ellesmere region, A. dieffenbachii was 
more abundant in the upper part of the estuary and $A$. australis was more abundant and more uniformly distributed throughout the estuary than were A. dieffenbachii (Jellyman et al. 2001). The salinity in all areas of this estuary ranged from freshwater or relatively low salinity, to nearly full strength seawater, depending on the season, so the eels in that estuary are also likely to experience a wide range of salinities if they remain within the same part of the estuary for several months or years. There also appears to be some habitat segregation within freshwater habitats, with $A$. australis predominating in lowland lakes, marshes and slower flowing stretches of streams and rivers, whereas $A$. dieffenbachii may prefer faster flowing water, larger sized substrates, and may generally penetrate further inland (McDowall 1990, Jowett \& Richardson 1995, Glova et al. 1998). However, both species appear to have substantial ecological plasticity, and their distributions appear to often overlap.

The apparent habitat use and movement patterns in this study support the findings of previous research on these 2 species, and also for other temperate eels that appear to typically have quite localized home ranges, but sometimes moving to different areas. For example, studies on Anguilla rostrata have found that their yellow eel stage has a restricted home range and that individuals return to their initial habitat after foraging outside their territory (Bozeman et al. 1985, Ford \& Mercer 1986, Oliveira 1997), or return to their home range after being artificially displaced (Parker 1995). Similarly, studies of New Zealand eels concluded that the large eels have relatively small home ranges and typically only move short distances within these streams (Burnet 1969, Chisnall \& Kalish 1993, Jellyman \& Sykes 2003). However, within Lake Ellesmere, the constant removal of eels by the commercial fishery means that available habitat is always opening up. This may explain why tagging and tracking studies found a tendency for individuals to remain within, or return to, a particular part of the lake, but that there was also significant movement among areas by some individuals (Jellyman et al. 1996).

Other factors that may result in the movement of eels between different habitats may be related to differential habitat use based on size or a diet shift toward piscivory that often occurs when yellow eels reach larger sizes. For example, in Lake Ellesmere the smaller juvenile eels of Anguilla australis $(<300 \mathrm{~mm})$ appeared to be more abundant closer to shore, but the larger eels were more evenly distributed and may be able to use a wider range of substrate types in the lake (Jellyman \& Chisnall 1999). Similarly, in a shallow lake on the North Island of New Zealand (Lake Waahi, $3.5 \mathrm{~m}$ max. depth), juvenile $A$. australis $(<380 \mathrm{~mm})$ were much more abundant in the lake margins than in the open water where the larger eels (mostly 325 to $500 \mathrm{~mm}$ ) predominated (Chisnall 1996). This type of habitat shift may be related to feeding, and in Lake Ellesmere A. australis yellow eels were found to shift to being almost exclusively piscivorous at sizes greater than $500 \mathrm{~mm}$ (Ryan 1986). Eels of this size would be predominantly females, and this would be similar to A. rostrata, which became piscivorous at a size that only female eels achieve (Krueger \& Oliveira 1997). Although all eels are feeding generalists (Helfman et al. 1987), smaller eels are more restricted because of their inability to ingest larger food items such as fish. Eels do not usually undergo a dramatic niche shift, but as their size increases, so does their niche breadth as a result of the inclusion of piscivory (Barak \& Mason 1992). Therefore, eels occupying a particular habitat with low abundances of fish may move to other areas to find greater concentrations of fish to feed upon.

Because of the potential variability in salinity in Lake Ellesmere, the causes of shifts in habitat or salinity levels by some of the eels examined in this study cannot be known for sure, but it confirms that these 2 species appear to display the same basic behavioral and physiological plasticity that has been observed in other temperate anguillid species. Both Anguilla australis and $A$. dieffenbachii are clearly able to remain in high salinity environments throughout most or all of their postlarval growth period. Other individuals also appear to switch habitats, as has been observed for other species (Tsukamoto et al. 1998, Tzeng et al. 2000, 2002, Tsukamoto \& Arai 2001, Jessop et al. 2002). Therefore, it appears that the phenomenon of facultative catadromy, with some individuals of temperate anguillid species entering freshwater but others remaining in marine environments, may not be restricted to northern temperate species. However, the presence of sea eels of these 2 species needs to be confirmed in high salinity areas outside of Lake Ellesmere and other highly enclosed estuaries (Jellyman et al. 2001) to determine whether sea residency is a characteristic of these 2 species or not. This information will be helpful to begin to identify which factors, such as habitat loss or degradation, or inter- or intra-species competition, may influence the occurrence of sea or estuarine residency in temperate anguillid eels.

Acknowledgements. We thank Dr. Steven Wing, University of Otago, for helpful discussion and Dr. Don Jellyman of the National Institute of Water and Atmospheric Research for sharing his knowledge about Lake Ellesmere. This work was supported in part by Grant-in-Aid Nos. 13760138, 15780130 and 15380125 from the Ministry of Education, Culture, Sports, Science, and Technology, Japan and Gould Aquafarms, the Division of Sciences of the University of Otago, New Zealand. 


\section{LITERATURE CITED}

Aoyama J, Miller MJ (2003) The silver eel. In: Aida K, Tsukamoto K, Yamauchi K (eds) Advances in eel biology. Springer-Verlag, Tokyo, p 107-117

Arai T, Otake T, Tsukamoto K (1997) Drastic changes in otolith microstructure and microchemistry accompanying the onset of metamorphosis in the Japanese eel, Anguilla japonica. Mar Ecol Prog Ser 161:17-22

Arai T, Otake T, Jellyman DJ, Tsukamoto K (1999) Differences in the early life history of the Australasian shortfinned eel, Anguilla australis from Australia and New Zealand, as revealed by otolith microstructure and microchemistry. Mar Biol 135:381-389

Arai T, Limbong D, Otake T, Tsukamoto K (2001) Recruitment mechanisms of tropical eels Anguilla spp. and implications for the evolution of oceanic migration in the genus Anguilla. Mar Ecol Prog Ser 216:253-264

Arai T, Kotake A, Ohji M, Miller MJ, Tsukamoto K, Miyazaki N (2003) Occurrence of sea eels of Anguilla japonica along the Sanriku Coast of Japan. Ichthyol Res 50:78-81

Barak NAE, Mason CF (1992) Population density, growth and diet of eels, Anguilla anguilla L., in two rivers in eastern England. Aquacult Fish Manage 23:59-70

Bertin L (1956) Eels-a biological study. Cleaver-Hume Press, London

Bozeman EK, Helfman GS, Richardson T (1985) Population size and home range of American eels in a Georgia tidal creek. Trans Am Fish Soc 114:821-825

Burnet AMR (1969) The growth of New Zealand freshwater eels in three Canterbury streams. NZ J Mar Freshw Res 3: 376-384

Cairns D (1941) Life-history of the two species of New Zealand fresh-water eel. Part I. Taxonomy, age and growth, migration, and distribution. NZ J Sci Tech 23: $53-72$

Campana SE (1999) Chemistry and composition of fish otoliths: pathways, mechanisms and applications. Mar Ecol Prog Ser 188:263-297

Chisnall BL (1989) Age, growth, and condition of freshwater eels (Anguilla spp.) in brackwaters of the Lower Waikato River, New Zealand. NZ J Mar Freshw Res 23:459-465

Chisnall BL, Hicks BJ (1993) Age and growth of longfinned eels (Anguilla dieffenbachii) in pastoral and forested streams in the Waikato River basin, and in two hydroelectric lakes in the North Island, New Zealand. NZ J Mar Freshw Res 27:317-332

Chisnall BL, Kalish JM (1993) Age validation and movement of freshwater eels (Anguilla dieffenbachii and A. australis) in a New Zealand pastoral stream. NZ J Mar Freshw Res 27:333-338

Ege V (1939) A revision of the genus Anguilla Shaw. Dana Rep 16 (13):8-256

Ford TE, Mercer E (1986) Density, size distribution and home range of American eels, Anguilla rostrata, in a Massachusetts salt marsh. Environ Biol Fish 17:309-314

Gerbeaux P (1993) Potential for re-establishment of aquatic plants in Lake Ellesmere (New Zealand). J Aquat Plant Manage 31:122-128

Glova GJ, Jellyman DJ, Bonnett ML (1998) Factors associated with the distribution of eels (Anguilla spp.) in three New Zealand lowland streams. NZ J Mar Freshw Res 32: 283-297

Graynoth E (1999) Improved otolith preparation, ageing and back-calculation techniques for New Zealand freshwater eels. Fish Res 42:137-146

Helfman GS, Facey DE, Hales LS, Bozeman EL (1987) Repro- ductive ecology of the American eel. In: Dadswell MJ, Klauda RJ, Moffitt CM, Saunders RL, Rulifson RA, Cooper JE (eds) Common strategies of anadromous and catadromous fishes. Am Fish Soc Symp 1:42-56

Horrell GA (1992) Lake Ellesmere water balance model: variable analysis and evaluation. M Eng Sci thesis, University of New South Wales, Sydney

Hughes HR, McColl RHS, Rawlence DJ (1974) Lake Ellesmere, Canterbury, New Zealand. A review of the lake and its catchment. New Zealand Department of Scientific and Industrial Research Information Series No. 99. Sigma Print, Petone, Wellington

Irwin J, Main W deL (1989) Lake Ellesmere bathymetry 1: 25 000. NZ Oceanogr Inst Chart, Lake Ser. NZ Oceanogr Inst, Div Water Sci, Dept Sci Indust Res, Wellington

Jellyman DJ (1987) Review of the marine life history of Australasian temperate species of Anguilla. Am Fish Soc Symp 1: 276-285

Jellyman DJ (1997) Variability in growth rates of freshwater eels (Anguilla spp. in New Zealand. Ecol Freshw Fish 6: 108-115

Jellyman DJ (2001) The influence of growth rate on the size of migrating female eels in Lake Ellesmere, New Zealand. J Fish Biol 58:725-736

Jellyman DJ, Chisnall BL (1999) Habitat preferences of shortfinned eels (Anguilla australis), in two New Zealand lowland lakes. NZ J Mar Freshw Res 33:233-248

Jellyman DJ, Sykes JRE (2003) Diel and seasonal movements of radio-tagged freshwater eels, Anguilla spp., in two New Zealand streams. Environ Biol Fish 66:143-154

Jellyman DJ, Todd PR (1998) Why are migrating male shortfinned eels (Anguilla australis) in Lake Ellesmere, New Zealand, getting smaller but not younger? Bull Fr Peche Piscic 349:141-152

Jellyman DJ, Glova GJ, Todd PR (1996) Movements of shortfinned eels, Anguilla australis, in Lake Ellesmere, New Zealand: results from mark-recapture studies and sonic tracking. NZ J Mar Freshw Res 30:371-381

Jellyman DJ, Glova GJ, Sagar PM, Sykes JRE (2001) Spatiotemporal distribution of fish in the Kakanui River estuary, South Island, New Zealand. NZ J Mar Freshw Res 30: 103-118

Jessop BM (1987) Migrating American eels in Nova Scotia. Trans Am Fish Soc 116:161-170

Jessop BM, Shiao JC, Iizuka Y, Tzeng WN (2002) Migratory behaviour and habitat use by American eels Anguilla rostrata as revealed by otolith microchemistry. Mar Ecol Prog Ser 188:263-297

Jowett IG, Richardson J (1995) Habitat preferences of common, riverine New Zealand native fishes and implication for flow management. NZ J Mar Freshw Res 29:13-23

Kawakami Y, Mochioka N, Morishita K, Tajima K, Nakagawa H, Toh H, Nakazono A (1998) Factors affecting otolith strontium/calcium ratios in Anguilla japonica elvers. Environ Biol Fish 52:299-303

Krueger WF, Oliveira (1997) Sex, size and gonad morphology of silver American eels, Anguilla rostrata. Copeia 1997: 415-420

Lineham IW (1983) Eutrophication of lake Ellesmere: a study of phytoplankton. PhD thesis, University of Canterbury, Christchurch

Lokman PM, Vermeulen GJ, Lambert JGD, Young G (1998) Gonad histology and plasma steroid profiles in wild New Zealand freshwater eels (Anguilla dieffenbachii and $A$. australis) before and at the onset of the natural spawning migration. I. Females. Fish Physiol Biochem 19: $339-347$ 
Marui M, Arai T, Miller MJ, Jellyman DJ, Tsukamoto K (2001) Comparison of early life history between New Zealand temperate eels and Pacific tropical eels revealed by otolith microstructure and microchemistry. Mar Ecol Prog Ser 213:273-284

McDowall RM (1990) New Zealand freshwater fishes: a natural history and guide. Heinemann Reed, Auckland

McDowall RM, Jellyman DJ, Dijkstra LH (1998) Arrival of an Australian anguillid eel in New Zealand: an example of transoceanic dispersal. Environ Biol Fish 51:1-6

Oliveira K (1997) Movement and growth rates of yellow phase American eels in the Annaquatucket River, Rhode Island. Trans Am Fish Soc 126:638-646

Oliveira K (1999) Life history characteristics and strategies of the American eel, Anguilla rostrata. Can J Fish Aquat Sci 56:795-802

Otake T, Ishii T, Nakahara M, Nakamura R (1994) Drastic changes in otolith strontium/calcium ratios in leptocephali and glass eels of Japanese eel Anguilla japonica. Mar Ecol Prog Ser 112:189-193

Panfili J, Ximenes MC, Crivelli AJ (1994) Sources of variation in growth of the European eel (Anguilla anguilla) estimated from otoliths. Can J Fish Aquat Sci 51:506-515

Parker SJ (1995) Homing ability and home-range of yellowphase American eels in a tidally dominated estuary. J Mar Biol Assoc UK 75:127-140

Pfeiler (1984) Glycosaminoglycan breakdown during metamorphosis of larval bone fish Albula. Mar Biol Lett 5: 241-249

Poole WR, Reynolds (1996) Growth rate and age at migration of Anguilla anguilla. J Fish Biol 48:633-642

Reid RE, Holmes RG (1996). Lake level control, flood hazard management, and drainage. In: Taylor KJW (ed) The natural resources of Lake Ellesmere (Te Waihora) and its catchment. Report 96(7), Canterbury Regional Council, Christchurch, p 51-83

Ryan PA (1986) Seasonal and size-related changes in the food of the short-finned eel, Anguilla australis in Lake Elles-

Editorial responsibility: Otto Kinne (Editor),

Oldendorf/Luhe, Germany mere, Canterbury, New Zealand. Environ Biol Fish 15: $47-58$

Sasai S, Aoyama J, Watanabe S, Kaneko T, Miller MJ, Tsukamoto K (2001) Occurrence of migrating silver eels, Anguilla japonica, in the East China Sea. Mar Ecol Prog Ser 212:305-310

Secor DH, Rooker JR (2000) Is strontium a useful scalar of life cycles in estuarine fishes? Fish Res 46:359-371

Sloane (1984) Invasion and upstream migration by glass-eels of Anguilla australis australis Richardson and A. reinhardtii Steindachner in Tasmanian freshwater streams. Aust J Mar Freshw Res 35:47-59

Tesch FW (1977) The eel. Biology and management of anguillid eels. Chapman \& Hall, London

Todd PR (1980) Size and age of migrating New Zealand freshwater eels (Anguilla spp.). NZ J Mar Freshw Res 14: 283-293

Todd PR (1981) Timing and periodicity of migrating New Zealand freshwater eels (Anguilla spp.). NZ J Mar Freshw Res 15:225-235

Tsukamoto K, Arai T (2001) Facultative catadromy of the eel, Anguilla japonica, between freshwater and seawater habitats. Mar Ecol Prog Ser 220:265-276

Tsukamoto K, Nakai I, Tesch FW (1998) Do all freshwater eels migrate? Nature 396:635-636

Tzeng WN (1996) Effects of salinity and ontogenetic movements on strontium:calcium ratios in the otoliths of the Japanese eel, Anguilla japonica Temminck and Schlegel. J Exp Mar Biol Ecol 199:111-122

Tzeng WN, Severin KP, Wickström (1997) Use of otolith microchemistry to investigate the environmental history of European eel Anguilla anguilla. Mar Ecol Prog Ser 149:73-81

Tzeng WN, Wang CH, Wickström H, Reizenstein M (2000) Occurrence of the semi-catadromous European eel Anguilla anguilla in the Baltic Sea. Mar Biol 137:93-98

Tzeng WN, Shiao JC, Iizuka Y (2002) Use of otolith Sr:Ca ratios to study the riverine migratory behaviors of Japanese eel Anguilla japonica. Mar Ecol Prog Ser 245:213-221

Submitted: June 12, 2003; Accepted: September 27, 2003

Proofs received from author(s): January 6, 2004 